\title{
Dawid LATAŁA
}

\section{CHARAKTERYSTYKA SYSTEMU KLASY ERP}

Na przykładzie oprogramowania SAP w artykule omówione zostały systemy klasy ERP, wykorzystywane przez przedsiębiorstwa do wspomagania zarządzania. Praca przedstawia problemy zwiazane z wdrożeniem tych systemów oraz korzyści, które wynikają z użytkowania oprogramowania klasy ERP.

\section{WSTĘP}

Rozwój technologii wytwarzania, zmiany otoczenia rynkowego przedsiębiorstw i zastosowanie technologii informatycznych w zarządzaniu i procesach wytwórczych spowodował zmiany w funkcjonowaniu i strukturze organizacyjnej przedsiębiorstw. Pojawienie się innowacji w technikach i metodach zarządzania wpłynęło na cykl życia organizacji. Globalizacja gospodarki, wzrost różnorodności produktów powodował skracanie cyklu życia wyrobów oraz pogłębianie indywidulanych potrzeb klienta. Zjawiska te wywołały niestabilność popytu. Zaczęły rosnąć wymagania dotyczące terminowości, szybkości i jakości dostaw. Widoczna stała się konkurencja między przedsiębiorstwami, poprzez wdrażanie radykalnych zmian. Organizacje tworzyły sieci współpracujących ze sobą przedsiębiorstw. W ten sposób narodziło się zapotrzebowanie na nowoczesne systemy informatyczne. Funkcjonalność ich koncentrowała się na wewnętrznych procesach organizacji oraz procesach w jej otoczeniu. Systemami tego typu stały się systemy klasy ERP [4].

\section{CHARAKTERYSTYKA SYSTEMU KLASY ERP}

System klasy ERP (ang. Enterprise Resource Planning) należy do grupy zintegrowanych systemów wspierających zarządzanie przedsiębiorstwem. Powstał on w wyniku rozwoju systemów wspomagających zarządzanie. Wcześniej istniały inne systemy, które wraz z rozwojem zmieniały się w coraz to bardziej zaawansowane i nowsze rozwiazania.

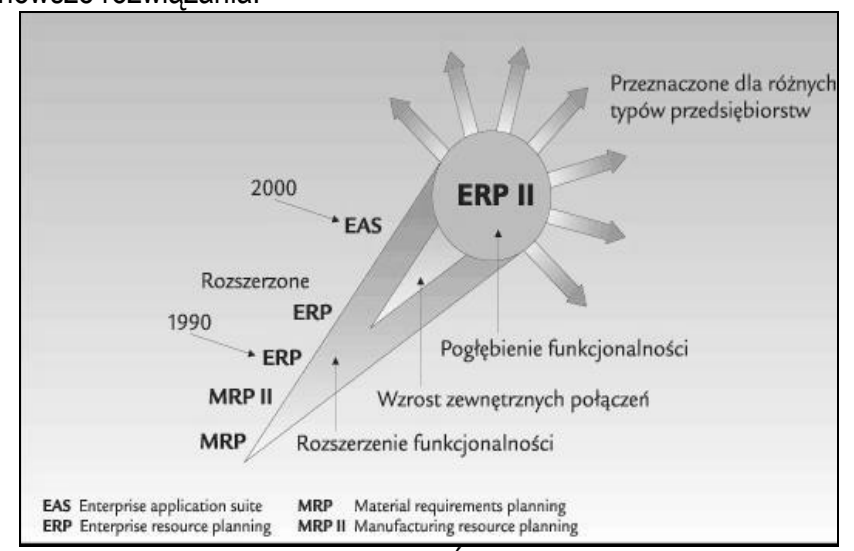

Rys. 1. Ewolucja systemów ERP. Źródło: oprac. własne na podst. [8]

Początkiem rozwoju zintegrowanych systemów były lata 50 -te ubiegłego wieku. Wtedy to powstały pierwsze systemy wspomagajace rejestrowanie gospodarki materiałowej, polegajace na automa- tyzacji czynności. W kolejnych latach XX w. pojawiły się techniki sterowania zapasami bazujące na metodzie prognozowania zamówień. Wykorzystywały one dane z poprzednich okresów o zużyciu zapasów w celu zaplanowania wielkości zapasów w przyszłości. Dalszy rozwój techniki informatycznej i wzrost poziomu obliczeń komputerów połączył w jeden system działania związane z planowaniem i prognozowaniem zamówień, wielkością dostaw, ustaleniem stanów magazynowych, itd. Przeobrażenia te doprowadziły do powstania systemu planowania potrzeb materiałowych MRP (ang. Material Requirements Planing) [3].

Systemy MRP powstały w latach 60 XX w.. Określały one potrzeby materiałowe, na podstawie których generowane były automatyczne zamówienia. W ten sposób przedsiębiorstwa mogły sprostać popytowi na produkty, określać terminy dostaw oraz dotrzymywać terminów realizacji zamówień. Cele systemów MRP określono następująco:

- wyznaczaja koszty produkcji,

- wpływają na redukcję zapasów,

- ustalają dokładne czasy dostaw półfabrykatów i surowców,

- optymalnie wykorzystuja powierzchnie magazynowe,

- szybko reagują na zmiany w otoczeniu,

- kontroluja poszczególne etapy produkcji.

Do właściwej realizacji tych celów niezbędne jest zasilanie systemu MRP bieżącymi danymi wejściowymi, do których zaliczamy [7]:

- harmonogram produkcji,

- dane dotyczące zapasów,

- czynniki planistyczne,

- informacje o podjętych zleceniach produkcyjnych i zleceniach zakupu.

Dane te z kolei pozwoliły na wykonywanie następujących procesów przez system: równoważenie zapotrzebowania z popytem i czasem realizacji zamówień oraz równoważenie czasu zapotrzebowania na produkty. W wyniku tych procesów możliwy stał się dostęp do informacji o harmonogramie zleceń zakupu i zleceń produkcyjnych.

Rozszerzenie systemów MRP o informacje zwrotne dotyczące wykonywania zaplanowanych zamówień i zdolności produkcyjnych doprowadziły do stworzenia systemu MRP w zamkniętej pętli, (ang. closed loop MRP) [4]. Zadaniem jego było oszacowanie, czy przedsiębiorstwo jest w stanie zrealizować plany zawarte w MRP, tzn. czy jego ilość zdolności produkcyjnej jest wystarczająca do realizacji planów. Zastosowanie sprzężenia zwrotnego pozwoliło na szybkie reagowanie na zmieniające się potrzeby produkcyjne.

Kolejnym etapem ewolucji zintegrowanych systemów są systemy MRP II(ang. Manufacturing Resource Planning), których zadaniem jest planowanie potrzeb produkcyjnych. Nowe rozszerzenie 
polegało na połączeniu poprzedniego systemu z procesami sprzedaży, powiązaniu z długookresowym planowaniem i finansami przedsiębiorstwa. System MRP II w odróżnieniu od MRP obejmuje swoim zasięgiem całe przedsiębiorstwo. Integruje czynności związane ze sprzedaża, wytwarzaniem i finansami. Umożliwia przetwarzanie zasobów produkcyjnych (urządzenia, usługi, materiały i personel) na cele finansowe oraz przedstawia rezultaty działalności produkcyjnej w ujęciu finansowym. Pomaga to oszacować finansowe zdolności przedsiębiorstwa w stosunku do wykonania planu. W ten sposób możliwe stało się określenie potrzeb materiałowych niezbędnych do procesu produkcji i uzyskanie koniecznych informacji analitycznych do zarządzania ekonomicznego [7].

Rozszerzenie systemu MRP II do systemu klasy ERP nastapiło w latach $90 \mathrm{XX}$ wieku. W rozszerzeniu tym pojawiły się procedury finansowe, tj. rachunkowość zarzadcza, rachunek kosztów, controlling, cah flow [6], co umożliwiło generowanie analiz finansowych przydatnych kierownictwu przedsiębiorstwa. System ERP umożliwił dostosowanie niezbędnych informacji na potrzeby użytkownika, symulację oraz analizę działań. Potencjalni użytkownicy systemu podczas podejmowania decyzji maja dostęp do jednej bazy danych. Zaletą stało się zintegrowanie i zautomatyzowanie procesów biznesowych poprzez dzielenie wspólnych danych w całym przedsiębiorstwie oraz generowanie informacji w czasie rzeczywistym. We wcześniejszych systemach korzystanie ze wspólnej bazy danych było niemożliwe, ze względu na to, że dane dostępne były tylko dla określonego obszaru działalności, a zdolności obliczeniowe niewystarczajace.

Słaba strona systemu ERP jest jednak wysoki koszt instalacji. Oprogramowanie ERP to jeden z kosztów implementacji systemu. Pociaga to za soba zastosowanie nowego i ulepszonego sprzętu komputerowego, który pozwoliłby na przetwarzanie dużych ilości danych. Szkolenie pracowników, konwersja istniejących danych na wspólny format, integracja i testy nowego systemu, utrzymanie systemu oraz konsultacje techniczne to kolejne koszty związane z wdrożeniem systemu planowania zasobów przedsiębiorstwa. Oprócz kosztów słabą stroną systemu jest również jego implementacja, z punktu widzenia terminowości. Proces ten okazuje się bardzo czasochłonny. Podczas implementacji w normalnym trybie dochodzi często do problemów związanych z instalacją i prawidłowym działaniem systemu, co prowadzi do zakłóceń w realizacji procesu produkcyjnego. W konsekwencji naraża przedsiębiorstwo na straty finansowe i niezadowolenie klientów.

Najnowszą generacja zintegrowanych systemów wspomagajacych zarządzanie przedsiębiorstwem jest system klasy ERP II następca ERP. Cechą odróżniająca ERPII od ERP jest to, że oprócz funkcji planowania zasobów finansowych i rzeczowych przedsiębiorstwa, pozwala na zarządzanie kontaktami z firmami partnerskimi albo klientami za pomoca podsystemu CRM (ang. Enterprise Resource and Relationship Processing) oraz zarządzanie łańcuchem dostaw - podsystem SCM (ang. Supply Chain Management) [5] Cechą nowego systemu jest możliwość komunikowania ze światem zewnętrznym poprzez sieć WWW. Analitycy firmy Gartner Group , którzy jako pierwsi wymusili istotne zmiany w systemie ERP, twierdzą, że system ERPII jest zbiorem aplikacji tworzących wartości dodane dla udziałowców i klientów przez udostępnienie procesów finansowych i decyzyjnych zarówno wewnątrz organizacji jaki i pomiędzy partnerami. Zauważyli również, że oprogramowanie podlega nieustannej ewolucji [4].

Systemy klasy ERP, które są kontynuacją systemów MRP i MRP II wdrażane są obecnie nie tylko w przedsiębiorstwach produkcyjnych, ale również w handlowych, usługowych, instytucjach państwowych i organizacjach non profit. Liczba użytkowników tego systemu stopniowo zwiększa się. Przybywa tym samym specjali- stów ds. wdrożenia i pojawia się coraz więcej nowych użytkowników systemu. Znajomość systemu jest coraz bardziej zauważalna na rynku polskim, przez co rośnie zapotrzebowanie na pracowników obsługujących ten system. Rozwój techniki daje przedsiębiorstwom i pracownikom XXI w. możliwość rozwoju oraz pewnej pozycji na rynku. Nowoczesny przedsiębiorca zyskuje miano konkurencyjnego dzięki zastosowaniu popularnego i wydajnego na rynku systemu klasy ERP.

\section{POJĘCIE I ROLA SYSTEMU ERP/SAP}

W literaturze istnieje wiele definicji systemu ERP. Jedną z nich określa APICS (ang. American Production \& Inventory Control Society) jako schemat organizacji, standaryzowania i definiowania procesów biznesowych koniecznych do efektywnego sterowania i planowania organizacja, za pomocą którego może wykorzystywać swoja wiedze do uzyskania przewagi konkurencyjnej. System ERP to zespół współpracujących aplikacji (modułów), opartych na scalonej bazie danych i wspierających wszystkie działy przedsiębiorstwa w zarzadzaniu.

Obecnie reprezentantem systemu ERP jest największy zintegrowany system informatyczny SAP. Został stworzony przez niemieckie przedsiębiorstwo informatyczne SAP AG założone w 1972 r. SAP-ERP jest jednym z najpopularniejszych systemów wspomagajacych zarządzanie przedsiębiorstwem na świecie. Korzysta z niego przeszło 12 mln użytkowników, a liczba firm korzystających z systemu przekroczyła 100 tys. w ponad 120 krajach. W Polsce liczba firm wykorzystujacych oprogramowanie SAP-ERP wzrasta. Obecnie jest ich ponad 1800.

SAP-ERP zyskał uznanie wśród przedsiębiorców z uwagi na to, że [2]:

- pozwala na elektroniczną wymianę danych i dokumentów,

- jest nieustannie rozwijany,

- dopasowywany do warunków otoczenia przedsiębiorstwa,

- umożliwia korzystanie z systemu niezależnie od systemów operacyjnych i platformy sprzętowej,

- umożliwia obsługę większości procesów w przedsiębiorstwie i integruje je w jeden system informatyczny,

- moduły i aplikacje mają taki sam interfejs użytkownika,

- możliwość dostosowania systemu do indywidualnych rozwiązań użytkownika,

- umożliwia zmianę funkcjonalności systemu do zmieniających się potrzeb.

Ponadto SAP-ERP integruje procesy biznesowe nie tylko wewnątrz przedsiębiorstwa, ale również w ramach „holdingu” organizacji rozlokowanych w kraju i za granicą oraz podmiotów niezależnych. Zastosowanie systemu daje przedsiębiorcom możliwość zarządzania w wielu aspektach, zaczynając od obszarów logistycznych, aż do nowoczesnych instrumentów „contollingowych”. Wdrożone rozwiązania w jednym kraju często mogą być zastosowane w innych. Producent oprogramowania SAP-ERP dając możliwość korzystania z wewnętrznego języka oprogramowania ABAP (ang. Advanced Business Application Programming) pozwala na modyfikację i wdrożenie indywidualnych rozwiązań biznesowych dla każdego użytkownika [2].

Architektura systemu SAP-ERP składa się z dwóch obszarów: funkcjonalnego i technicznego. Pierwszy z nich to podział systemu na moduły funkcjonalne. Najbardziej ogólny podział wyróżnia trzy główne grupy modułów: logistyka, finanse i zarządzanie zasobami ludzkimi. W skład logistyki wchodza:

- SD/sprzedaż i dystrybucja - system pozwala na rejestrowanie i obsługę procesów handlowych poprzedzających dostawę do klienta zamówionych usług i towarów. Najważniejsza rola sys- 
temu w tym obszarze to rejestrowanie transakcji sprzedaży, obsługa dokumentów handlowych, kontrola towarów, przeniesienie zapotrzebowań sprzedaży do obsługi planowania potrzeb materiałowych, tworzenie harmonogramu dostaw, sterowanie partia towarów wg metody FIFO, LI-FO, zarządzanie obsługa serwisowa, obliczanie cen i rabatów, kontrolowanie limitów kredytowych, drukowanie dokumentów, obsługa faktur i zwrotów, wysyłka i transport towarów, oraz możliwość elektronicznej wymiany danych w systemie EDI (transfer danych transakcyjnych pomiędzy stronami kontraktu).

- MM/gospodarka materiałowa - obsługa logistyczna w obszarze planowania potrzeb materiałowych, zaopatrzenia materiałowego, zarządzania zapasami, wycena materiałową oraz logistyczne przyjmowanie i sprawdzanie faktur. Rolą tego modułu jest mocny związek z modułami finansowymi i pozostałymi modułami logistycznymi. Integruje się z planowaniem produkcji, gospodarką magazynową i remontowa.

WM/gospodarka magazynowa - umożliwia definiowanie struktur magazynowych, przy jednoczesnym administrowaniu nimi. Funkcjonalność modułu WM wykorzystywana jest przy zarzadzaniu magazynami ze specjalnymi miejscami składowania lub magazynami wysokiego składowania. Moduł ten określa miejsca w magazynie, w których materiał powinien być umieszczany, z których powinien zostać pobrany oraz w których następuje kompletacja zlecenia.

- PP/planowanie produkcji - najobszerniejszy moduł systemu SAP-ERP, który obsługuje dane materiałowe, specyfikacje materiałowe, zarządza marszrutami technologicznymi, stanowiskami roboczymi, zdolnościami produkcyjnymi, pozwala na planowanie zasobów produkcyjnych, harmonogramowanie produkcji wg prognoz i planów sprzedaży, kontroluje wykorzystanie mocy produkcyjnych, umożliwia określenie kosztów produkcji wyrobów oraz monitoruje etapy realizacji procesu produkcyjnego.

- QM/zarządzanie jakością - wspiera działania przedsiębiorstwa w zakresie kontroli i planowania jakości. Umożliwia tworzenie certyfikatów jakości i ich kontrolę oraz zarządza problemami jakościowymi. Moduł ten funkcjonuje zarówno w obszarze zaopatrzenia jak i sprzedaży.

- PM/gospodarka remontowa - znajduje się w logistycznej części SAP-ERP. Poprzez integrację z innymi modułami wspiera działania przedsiębiorstwa w zakresie realizacji i kontroli remontów. Wspomaga procesy gospodarki remontowej w obszarze struktury organizacyjnej utrzymania ruchu, inwestycji i remontów, pozwala na zarządzanie obiektami gospodarki remontowej, pomaga w planowaniu i wykonywaniu bieżących działań remontowych oraz tworzy system in-formacyjny gospodarki remontowej.

Moduł wspomagający zarządzanie finansami przedsiębiorstwa obejmuje: Fl/rachunkowość finansową (tworzenie sprawozdań, bilansów, rachunków zysków i strat), CO/controlling (analiza kosztowo-przychodowa, budżetowanie i planowanie kosztów, rozliczenia kosztów), IM/zarządzanie inwestycjami (tworzenie planów, projektów i zleceń inwestycyjnych oraz ich rozliczanie), PS/system projektowy (planowanie i realizacja projektów badawczych, rozwojowych, remontowych itp.), RE/zarządzanie nieruchomościami (komercyjne zarządzanie leasingiem nieruchomości, budżetowanie i rozliczanie) oraz FM/rachunkowość budżetowa (planowanie, monitorowanie realizacja wydatków i dochodów przedsiębiorstwa).

W module zarzadzania zasobami ludzkimi przedsiębiorstwo rozlicza listę płac/ HR-PY. Moduł ten ułatwia regularne naliczanie listy płac, tworzenie raportów na potrzeby ZUS i US. Ponadto wspomaga rozliczanie płac z uwzględnieniem wszystkich składników wynagrodzenia, potrąceń, składek i zaliczek na podatek oraz zwolnień chorobowych. Funkcjonalność modułu pozwala na rozliczanie pracowników etapowych, zatrudnionych na umowy o dzieło czy też umowy zlecenia. Integracja z modułem rachunkowości finansowej i controllingu pozwala na wymianę danych i wyświetlaniu ich w czasie rzeczywistym.

Obszar techniczny systemu SAP-ERP to przede wszystkim administracja systemu- nadzorowanie i zapewnienie dostępności systemu przez działy informatyczne. Umożliwianie integracji systemu z innymi systemami, tworzenie kopii zapasowych, rozwiazywanie problemów łączności sieciowej, bezprzewodowej, itp. Praca w języku ABAP pozwala na dokonywanie zmian w systemie i tworzenie programów realizujących indywidualne wymagania użytkowników. Duże znaczenie dla klientów SAP-ERP ma dostęp do kodu źródłowego, który wykorzystuje wiedzę o zasadach działania systemu podczas dostosowywania systemu do specyfiki działalności przedsiębiorstwa.

Głównym zadaniem systemu ERP jest zapewnienie użytkownikom bezpieczeństwa wprowadzanych danych. Dane gromadzone w systemie są narażone na zagrożenia związane z utratą danych poprzez niewłaściwą obsługę oprogramowania, awarię sprzętu, błąd administratora, atak zewnętrzny, czy też inne zdarzenia losowe. Aby tego uniknąć należy stworzyć takie zabezpieczenia, które w skrajnym przypadku pozwolą na przywrócenie danych. Nie istnieje jeden uniwersalny sposób ochrony danych. Stosuje się wiele metod zabezpieczeń jak np. uświadamianie i kształcenie użytkowników, dostęp tylko do określonych modułów i czynności w zakresie wykonywanej pracy, zabezpieczenie serwera, ograniczenie dostępu do zasobów IT, tworzenie centrum zapasowego.

\section{PODSUMOWANIE}

Przedsiębiorstwa decydujące się na wymianę starego systemu i wdrożenie nowego typu SAP-ERP kieruja się przede wszystkim korzyściami wynikającymi z jego użytkowania. Stosowanie systemu SAP-ERP umożliwia znaczną redukcję kosztów dla przedsiębiorstwa. Wprowadzenie automatyzacji pracy, kontrola wydajności i skuteczności zarządzania zasobami przedsiębiorstwa, weryfikacja planów produkcyjnych, kontrola kosztów przy wykorzystaniu narzędzi controllingowych to kryteria oszczędności kosztów. Oszczędność czasu natomiast realizowana jest przez sprawniejsze wykonywanie czynności za pomocą systemu i sprawniejsze pozyskiwanie różnorodnych informacji. Procesy biznesowe przedsiębiorstwa ulegają standaryzacji i usprawnieniu, poprzez reorganizację procesów zachodzących w przedsiębiorstwie, ocenę realizacji procesów, przygotowanie i weryfikację wykonania planu, wykorzystanie wzorców procesów biznesowych oraz „benchmarking” gospodarczy (analiza porównawcza). Wprowadzenie scentralizowanej bazy danych, rejestrów danych w każdej komórce organizacyjnej i walidacja ewidencji danych, staje się zaletą korzystania z systemu. Przedsiębiorca odnosi korzyści także poprzez polepszenie jakości obsługi klienta. System pozwala na skrócenie czasu komunikowania się z klientem, dając szybką odpowiedź na zapytania klienta, generuje czytelną dokumentację obrotu materiałowego oraz efektywnie rozpoznaje potrzeby klienta.

Wkroczenie gospodarki przedsiębiorstw na rynki światowe wymusza posiadanie nowoczesnego oprogramowania, który pozwoli na integrację, tworzenie i współpracę w skali globalnej. Gwarantem tego jest system SAP-ERP. Łączy wszystkie jednostki przedsiębiorstwa, często ulokowane na różnych rynkach w jedną całość. Pozwala na kierowanie, planowanie, zarządzanie i kontrolę różnorodnych kooperacji, dostosowując potrzeby poszczególnych działów przedsiębiorstw do siebie. Ponadto stosowanie systemu SAP przez przedsiębiorstwa powoduje: 
- przekształcanie przedsiębiorstw w jednostki oparte na informacjach - informacja stała się podstawowym zasobem przedsiębiorstwa. Zaczęły być wykorzystywane do pokrycia operacyjnych potrzeb przedsiębiorstwa. System umożliwił wielokrotne ich wykorzystywanie i współdzielenie, bez negatywnych konsekwencji,

- odzwierciedlenie zintegrowanej struktury przedsiębiorstwa system obejmuje całe przedsiębiorstwo, jak i jego poszczególne działy. Korzystając z systemu SAP-ERP przedsiębiorstwa unikają problemów związanych z różnymi interfejsami, ograniczeniami aktualizacji i kompatybilnością. Możliwa staje się praca grupowa, która pomaga na eliminowanie niezgodności między działami danej organizacji,

- przekształcanie przedsiębiorstwa zorientowanego na klienta dzięki szybkiemu obiegu i przetwarzaniu informacji przedsiębiorstwa kontroluja przebieg procesów gospodarczych w relacjach wewnętrznych i zewnętrznych,

- pracę w rzeczywistym czasie - podczas operacji biznesowych następuje bezpośrednie wprowadzanie danych do systemu przez co przedsiębiorstwo ma dostęp do aktualnych danych. Praca w systemie daje możliwość wykonywania wiele czynności równolegle,

- nadanie rangi strategii biznesowej branży IT - system SAP-ERP stał się kluczowym czynnikiem w stworzeniu efektywnego przedsiębiorstwa. Znaczenie systemów informatycznych dla przedsiębiorstwa wyraźnie wzrosło przez co możliwe stało się rozwiązywanie wielu problemów organizacji. Wdrożenie systemu daje przedsiębiorcom przewagę nad konkurencją,

- wzrost wydajności produkcyjnej - dzięki zastosowaniu systemu wspierającego planowanie zasobów produkcyjnych możliwe stało się zwiększenie wydajności produkcyjnej. Strategia zarzadzania zapasami JIT (dostawa na czas), kompleksowe zarządzanie jakością TQM, odchudzona produkcja (ang. lean manufacturing) to jedne $z$ wielu metod stosowanych przez nowoczesne przedsiębiorstwa w procesie zwiększania wydajności produkcyjnej,

- wdrożenie systemów komputerowych poprzez wprowadzenie nowego modelu - możliwość stworzenia własnego modelu systemu informatycznego, zgodnego z wymaganiami przedsiębiorstwa. Dostosowanie systemu SAP-ERP w znacznym stopniu ułatwiło pracę projektantów IT eliminując zbieranie odpowiednich wymagań, języków modelowania czy testowania,
- ogólnie dostępne środowisko użytkownika - system SAP-ERP kładąc nacisk na użytkownika końcowego pozwala na pracę w przyswajalnym i akceptowalnym środowisku.

\section{BIBLIOGRAFIA}

1. Amanowicz A.: „CEO. Magazyn Top Menedżerów; ERP II narodziny nowego standardu", IDG Poland 2003,

2. Auksztol J., Balwierz P., Chomuszko M.: „SAP zrozumieć system ERP”, Wydawnictwo Naukowe PWN, Warszawa 2013

3. Długosz J.: „Nowoczesne technologie w logistyce”, Polskie Wydawnictwo Ekonomiczne, Warszawa 2009

4. Klonowski Z.J.: „Systemy informatyczne zarzadzania przedsiębiorstwem, Modele rozwoju i właściwości funkcjonalne", Oficyna Wydawnicza Politechniki Wrocławskiej, Wrocław 2004

5. Lech P.: „Zintegrowane systemy zarządzania ERP/ERPII”, Difin, Warszawa 2003

6. Murphy P.R., Wood D.F.: „Nowoczesna logistyka”, Wydanie X, Wydawnictwo Helion S.A., Gliwice 2011

7. Wieczerzycki W.: „E-logistyka”, Polskie Wydawnictwo Ekonomiczne, Warszawa 2012

8. Źródło internetowe: http://edu.pjwstk.edu.pl/wyklady/tpb/scb/index84.html z dn. 17.03.2018

\section{Characteristics of ERP class system}

On the example of SAP software, the article discusses ERP class systems used by enterprises to support management. The work presents problems related to the implementation of these systems and the benefits that result from the use of ERP class software

Autorzy:

mgr inż. Dawid Latała - Politechnika Rzeszowska im. Ignacego

Łukasiewicza, Wydział Budowy Maszyn i Lotnictwa, Katedra

Technologii Maszyn i Inżynierii Produkcji

JEL: L63 DOI: 10.24136/atest.2018.256

Data zgłoszenia: 2018.05.29 Data akceptacji: 2018.06.15 